\title{
ANALISIS CEMARAN LIMBAH INDUSTRI DAN DOMESTIK TERHADAP BIOTA LAUT DI PERAIRAN KOTA TANJUNGPINANG, PROVIPNSI KEPULAUAN RIAU
}

Contamination Analysis Of Industrial Waste And Domestic Water City Marine Life In Tanjungpinang, Riau Islands Province

\author{
Oleh : \\ Agus Susanto ${ }^{1}$, Hurip Pratomo ${ }^{2}$ dan Arief Rahman ${ }^{3}$ \\ ${ }^{1}$ Perencana Wilayah \& Kota FMIPA Universitas Terbuka \\ ${ }^{2}$ Biologi FMIPA Universitas Terbuka \\ ${ }^{3}$ Pendidikan Kimia, FMIPA Universitas Negeri Jakarta \\ Pusat Teknologi Lingkungan, BPPT \\ Jl. M.H. Thamrin No. 8 Gd. II Lt. 18 Jakarta 10340
}

\begin{abstract}
Abstrak
Sektor industri merupakan prioritas kedua dalam pengembangan kota Tanjungpinang, sehingga yang berkembang adalah industri pertambangan, industri pengolahan, transportasi dan makanan. Masyarakat mempunyai anggapan bahwa industri kecil adalah industri yang tidak mengancam lingkungan, sehingga limbah dari industri skala kecil terkadang diabaikan karena dianggap tidak terlalu signifikan, dan tidak terlalu berbahaya, padahal limbah B3 yang terkandung dalam limbah domestik dapat menyebabkan terganggunya biota laut dan ekosistemnya, dan berpotesi akan memusnahkannya. Penelitian ini bertujuan menjelaskan besaran dampak pencemaran limbah B3 dan domestik terhadap lingkungan perairan laut terutama terhadap biota laut, dan memberikan masukan kepada Pemerintah Provinsi mengenai rumusan strategi pengelolaan lingkungan perairan Kota Tanjungpinang. Untuk keperluan analisis diambil 10 sampel air, dan 15 biota perairan pada lokasi yang berbeda. Sedangkan analisis bahan pencemar secara kuantitatif dilakukan dengan mengamati populasi unsur-unsur bahan berbahaya dari sampel sedimen, air, dan jaringan biota. Analisis kandungan sampel digunakan teknik XRF (X-Ray Fluoresensi), AAS (Atomic Absorbance Spectroscopy). Adapun indeks pencemaran digunakan pendekatan perbandingan konsentrasi logam yang diukur dengan konsentrasi logam standar daerah belum tercemar. Hasil menjelaskan perairan laut pesisir kota Tanjungpinang telah tercemar logam berat, dengan kriteria tercemar sedang hingga berat dengan indeks pencemaran 2.91 - 5.96 yaitu logam-logam $\mathrm{As}, \mathrm{Cd}, \mathrm{Cu}, \mathrm{Pb}, \mathrm{Zn}$, dan Ni. Logamlogam yang terkait dengan aktivitas manusia di bidang industri perkapalan yakni $\mathrm{Pb}$ dan $\mathrm{Zn}$ yang merupakan komponen utama dalam cat. Sedangkan kompoisi logam berat seperti Arsen (As), Kadmium (Cd), Tembaga (Cu) diduga berasal dari aktivitas pertambangan bauxite, Sementara tingginya kadar nitrat merupakan penanda adanya aktivitas pertanian yang menggunakan pupuk dan sisanya terbuang ke perairan kota Tanjungpinang, dan ditemukan juga pencemaran E-coli dari kotoran manusia. Biota yang hidup di perairan Kota Tanjungpinang telah tercemar logam berat melalui bioakumulasi yakni $\mathrm{Hg}$, Zn, dan Ar yang terkait aktivitas industri pengolahan bauksit di masa lalu. Pencemaran logam berat paling tinggi pada Kijing (Pilsbryoconcha exillis) yang meliputi: $\mathrm{Hg}, \mathrm{Cr}, \mathrm{As}, \mathrm{Cu}, \mathrm{Zn}, \mathrm{Ni}$, dan pada ikan-ikan dimersal yang pergerakannya terbatas. Masukan yang diberikan adalah agar pemerintah Provinsi melakukan reforestasi mangrove disepanjang pesisir dan muara sungai, dan membuat Penetapan kawasan konservasi laut daerah (KKLD) di perairan selat Dompak.
\end{abstract}

Kata Kunci: logam berat, biota laut, pesisir kota Tanjungpinang, mangrove

\begin{abstract}
Industrial sector is the second priority in development of Tanjungpinang city. The mining industry, processing industry, transport and food are thriving. People has the opinion that a small industry is an industry that does not threaten the environment, so that the small-scale industrial waste are sometimes were forgotten due to it is not significant, and not too dangerous, whereas the B3 waste contained in domestic waste can cause disturbance of marine life and the ecosystem this
\end{abstract}


will have potential to destroy the ecosystem. This study aims to explain the impact of B3 and domestic waste pollution to the environment, especially marine waters to marine life, and feedback to the provincial government for the formulation strategy of the management of the Tanjungpinang waters environment. For the analysis, 10 water samples and 15 aquatic biota was taken at different locations. While the quantitative analysis of pollutants carried by observing a population of the elements of hazardous substances from sediment samples, water and biota network. XRF techniques (X-Ray Fluorescence) and AAS (Atomic Absorbance Spectroscopy) used for the analysis content of the samples. The pollution index determined by compare metal concentration ratio the polluted areas with the standard metal concentration areas that were not polluted. The results show that the coastal water of tanjungpinang have been contaminated by heavy metals ( $\mathrm{As}, \mathrm{Cd}, \mathrm{Cu}, \mathrm{Pb}, \mathrm{Zn}$, and Ni) with pollution index 2.91 - 5.96. The pollutant Metals were came from the human activities in the shipbuilding industry usually $\mathrm{Pb}$ and $\mathrm{Zn}$ which is the main component of the paint. While heavy metals such as arsenic (As), Cadmium (Cd), copper (Cu) probably derived from bauxite mining activity, the high levels of nitrate is a sign of agricultural activities that use fertilizers. Unfortunately the rest of it discharged into the coastal waters of Tanjungpinang city, and there is also pollution of E-coli from human waste. Biota that live in the waters of Tanjungpinang have been contaminated by heavy metals $(\mathrm{Hg}, \mathrm{Zn}$, and $\mathrm{Ar})$ by bioaccumulation. The related activity of the pollutant was the bauxite processing industry in the past. Heavy metal pollution is highest in Kijing (Pilsbryoconcha exillis) which includes: $\mathrm{Hg}, \mathrm{Cr}, \mathrm{As}$, $\mathrm{Cu}, \mathrm{Zn}, \mathrm{Ni}$, and the dimersal fish that have limited movement. Feedback given is that provincial governments do mangrove reforestation along the coast and estuaries, and create marine conservation areas determination of areas (KKLD) in the strait Dompak water.

Key Words : heavy metals, marine life, coastal water of tanjungpinang, mangrove

\section{LATAR BELAKANG}

Sejak diberlakukannya Undang-undang No. 25 tahun 2002 yang menyebutkan bahwa ibu kota Provinsi Kepulauan Riau adalah kota Tanjungpinang, maka fungsi kotanya adalah sebagai pusat pemerintahan, jasa, pusat perekonomian, dan pendidikan, serta pariwisata, sedangkan kegiatan usaha industri merupakan sektor kedua yang dikembangkan, sehingga memberikan sumbangan terbesar kedua bagi PDRB Kota Tanjungpinang yang diperoleh dari sektor industri pengolahan dengan memberikan kontribusi sebesar 19,10\% (BPS Kota Tanjungpinang, 2012).

Akibat perubahan fungsi kota tersebut, maka arus urbanisasi meningkat, yang berpengaruh pada jumlah penduduk. Pertumbuhan jumlah penduduk secara tidak langsung tentu mempengaruhi pertumbuhan industri skala kecil dan menengah yang berperan dalam memberi warna dan geliat perekonomian di Kota Tanjungpinang, mulai dari industri makanan, kerajinan tangan, mebel, hingga konveksi atau tekstil, serta industri pertambangan. Perkembangan sektor industri akan berdampak pada pemakaian sumberdaya alam yang ada. Sumber daya alam yang ada akan dieksplorasi, diekstraksi, ditranformasi menjadi suatu produk. Selain itu, sumberdaya alam juga dimanfaatkan sebagai sumber energi, yang tidak terpakai mengakibatkan limbah.

Kegiatan industri dengan mengekstrak sumberdaya alam dilakukan agar dapat meningkatkan kualitas, daya guna dan nilai jual sumberdaya tersebut, akan tetapi berpotensi menimbulkan dampak negatif yaitu adanya limbah akibat proses produksi dan produk yang dihasilkan serta kemungkinan terjadinya degradasi terhadap sumberdaya yang digunakan.

Disamping itu, sebagian besar masyarakat kota Tanjungpinang menganggap bahwa industri kecil adalah industri yang tidak berpotensi menimbulkan pencemaran terhadap lingkungan, sehingga limbah dari industri skala kecil terkadang diabaikan karena besaran usahanya yang dianggap tidak terlalu signifikan, dan tidak terlalu berbahaya sehingga tidak perlu diatur secara seksama. Sementara sistem pengolahan air limbah di Kota Tanjungpinang saat ini belum dilakukan secara maksimal. Sistem yang digunakan adalah, sebagian besar masyarakat membuang limbah rumah tangga masih dengan sistem septic tank yang selanjutnya dibuang ke drainase terbuka kota yang akhirnya masuk ke perairan kota Tanjungpinang (Bappeda, 2012).

Limbah cair domestik dan industri (domestic and industrial sewage) merupakan masalah pencemaran yang paling besar di wilayah perairan Provinsi Kepulauan Riau, khususnya di Kota Tanjungpinang. Hal ini umumnya disebabkan karena tidak atau kurang memadainya fasilitas untuk menangani dan mengelola limbah cair domestik dan industri. Buangan limbah dari kegiatan pabrik atau industri dalam bentuk padat dan cair sangat potensial mengandung bahan berbahaya dan beracun (B3). 
Sedangkan limbah domestik sebagian besar berasal dari pemukiman penduduk, rumah makan/restoran dan hotel di sepanjang pantai dalam bentuk cair dan padat berupa air cucian yang mengandung detergen, air bekas mandi yang mengandung sabun, minyak goreng bekas dan sisa makanan dan lain-lain. Dampak dari pencemaran limbah B3 dan domestik terhadap perairan laut dapat menyebabkan terganggunya biota laut dan ekosistemnya, dan apabila tidak ditangani dengan secepatnya kemungkinan akan memusnahkan biota laut.

Dari fenomena tersebut, maka dalam penelitian ini mempunyai tujuan: menjelaskan besaran dampak pencemaran limbah B3 dan domestik terhadap lingkungan perairan laut terutama terhadap biota laut, dan memberikan masukan kepada Pemerintah Provinsi mengenai rumusan strategi pengelolaan lingkungan perairan Kota Tanjungpinang.

\section{METODOLOGI}

Penelitian yang digunakan adalah deskriptif kuantitatif dengan mengambil beberapa sample air, biota dan sedimen, kemudian sampel tersebut dianalisis di Laboratorium ProLink Fakultas Perikanan Institut Pertanian Bogor, dan Laboratotium Pusat Survei Geologi Bandung. Untuk analisis kualitas air laut digunakan Kepmen LH No. 51 Tahun 2004. Lokasi pengambilan sampel beserta deskripsi kegiatan masyarakat disajikan Tabel 1, dan Gambar 1.

\subsection{Penetapan Bahan Pencemar Limbah B3}

Untuk menetapkan sejauh mana kadar bahan pencemar yang sudah diketahui ditetapkan dari informasi yang ada, dan dampak yang mungkin tampak secara visual. Penetapan bahan pencemar secara kuantitatif akan dilakukan dengan mengamati populasi unsur-unsur bahan berbahaya pada sampel sedimen, pada air, dan pada jaringan biota, menggunakan teknik XRF (X-Ray Fluoresensi), AAS (Atomic Absorbance Spectroscopy) untuk sampelsampel yang dianggap mewakili baik untuk sedimen maupun air dan jaringan pada biota.

\subsection{Penentuan bahan pencemar menggunakan teknik XRF untuk sedimen.}

Sedimen yang diambil sebagai sampel dengan memperhitungkan keterwakilan dan karakteristk lokasi pengambilan sampel dikeringkan dan dihaluskan. Pengukuran dilakukan untuk memeriksa semua unsur yang dikandung oleh sedimen. Dengan teknik ini, seluruh komponen logam berbahaya yang diduga berperan sebagai pencemar dapat ditentukan.

\subsection{Penentuan Bahan pencemar menggunakan teknik AAS untuk sampel air laut dan biota.}

Informasi awal yang diperoleh dari analisis sedimen menggunakan teknik XRF dapat digunakan sebagai dasar untuk memeriksa kandungan logam berat yang mencemari lingkungan yang eksis di air laut maupun di tubuh biota. Sampel air laut diambil dan diawetkan menggunakan asam nitrat $\left(\mathrm{HNO}_{3}\right)$ pada waktu pengambilan sampel dan dilakukan penyaringan sebelum ditentukan kandungan logam beratnya menggunakan AAS. Untuk sampel biota, sampel yang diperiksa dikeringkan terlebih dahulu dan didestruksi untuk memperoleh sampel yang siap dianalisa.

\subsection{Penentuan Index pencemar}

Untuk menentukan indeks pencemaran di perairan kota Tanjungpinang digunakan pendekatan perbandingan konsentrasi logam yang diukur dengan konsentrasi logam standar daerah belum tercemar dengan persamaan:

$$
\begin{gathered}
C F=\frac{\text { Clogam }}{\text { C baseline }} \\
P L I=\left(\mathrm{CF}_{1} \times \mathrm{CF}_{2} \times \mathrm{CF}_{3} \times \mathrm{CF}_{4} \times C F n\right)^{1 / n}
\end{gathered}
$$

Dimana:

$$
\begin{array}{ll}
\mathrm{CF} & =\text { Contamination Factors } \\
\text { Clogam } & =\text { Konsentrasi logam yang diukur } \\
\text { Cbaseline } & =\text { Konsentrasi logam standar daerah elum } \\
& \text { tercemar } \\
\mathrm{PLI} & =\text { Pollution Load Index (Indeks } \\
& \text { pencemaran) }
\end{array}
$$

Tabel 1. Lokasi Pengambilan Sampel

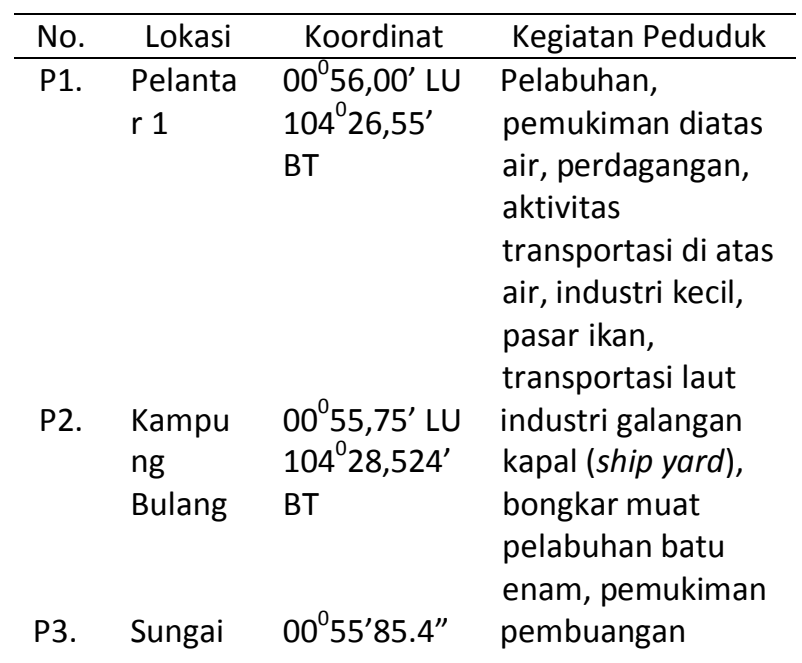




\begin{tabular}{|c|c|c|c|c|c|c|c|}
\hline No. & Lokasi & Koordinat & Kegiatan Peduduk & No. & Lokasi & Koordinat & Kegiatan Peduduk \\
\hline \multirow{12}{*}{ P4. } & Carang & LU & limbah cair dari & \multirow{3}{*}{ P7. } & & "BT & \multirow{3}{*}{$\begin{array}{l}\text { Pemukiman darat } \\
\text { dan laut, hutan } \\
\text { bakau }\end{array}$} \\
\hline & & $104^{0} 29^{\prime} 65.9$ & RSUP, dan & & Lembah & $00^{0} 54^{\prime} 03.6^{\prime \prime}$ & \\
\hline & & " BT & $\begin{array}{l}\text { buangan air } \\
\text { bersih/filtrasi }\end{array}$ & & $\begin{array}{l}\text { Purnam } \\
\text { a }\end{array}$ & $\begin{array}{l}\text { LU } \\
104^{0} 27^{\prime} 32.5\end{array}$ & \\
\hline & & & Kolam tailing eks & \multirow{5}{*}{ P8. } & \multirow{5}{*}{ Sei Jang } & "BT & \multirow{8}{*}{$\begin{array}{l}\text { pemukiman, } \\
\text { pelabuhan bongkar } \\
\text { muat, shipyard, } \\
\text { dan pembuatan } \\
\text { kapal fiber } \\
\text { Mangrove dan } \\
\text { lamun }\end{array}$} \\
\hline & & & tambang Bouksit & & & $00^{0} 53^{\prime} 65.4^{\prime \prime}$ & \\
\hline & & & dan tailing ke & & & LU & \\
\hline & & & perairan pasang & & & $\begin{array}{l}1042815.1 \\
\text { "RT }\end{array}$ & \\
\hline & & & daerah situs Sei & & & & \\
\hline & & & timun, sei riau ke & \multirow[t]{3}{*}{ P9. } & \multirow{2}{*}{$\begin{array}{l}\text { Jembat } \\
\text { an }\end{array}$} & $00^{\circ} 52^{\prime} 44.8^{\prime \prime}$ & \\
\hline & & & dan sei carang & & & LU & \\
\hline & Sei & $00^{0} 56^{\prime} 22.9^{\prime \prime}$ & pemukiman dari & & Dompa & $104^{0} 29^{\prime} 65.0$ & \\
\hline & Terusan & & darat dan aliran air & & & "BT & \\
\hline & & $\begin{array}{l}104^{0} 28^{\prime} 24.3 \\
\text { " BT }\end{array}$ & $\begin{array}{l}\text { pasang surut dari } \\
\text { darat ke laut }\end{array}$ & P10 & $\begin{array}{l}\text { Teluk } \\
\text { Keriting }\end{array}$ & $\begin{array}{l}00^{0} 55^{\prime} 41.2^{\prime \prime} \\
\mathrm{LU}\end{array}$ & $\begin{array}{l}\text { Pemukiman, } \\
\text { rumah sakit, }\end{array}$ \\
\hline P5. & Kampun & $00^{0} 56^{\prime} 45.6^{\prime \prime}$ & Nelayan, SPBU, & & & $104^{0} 26^{\prime} 28.0$ & laundry \\
\hline & g Bugis & LU & shipyard, kapal & & & "BT & \\
\hline
\end{tabular}

$104^{0} 26^{\prime} 62.5$ berlabuh

"BT

P6. Pantai $00^{\circ} 54^{\prime} 06.5^{\prime \prime}$ Pemukiman dan

Impian LU hotel

$104^{0} 26^{\prime} 94.4$

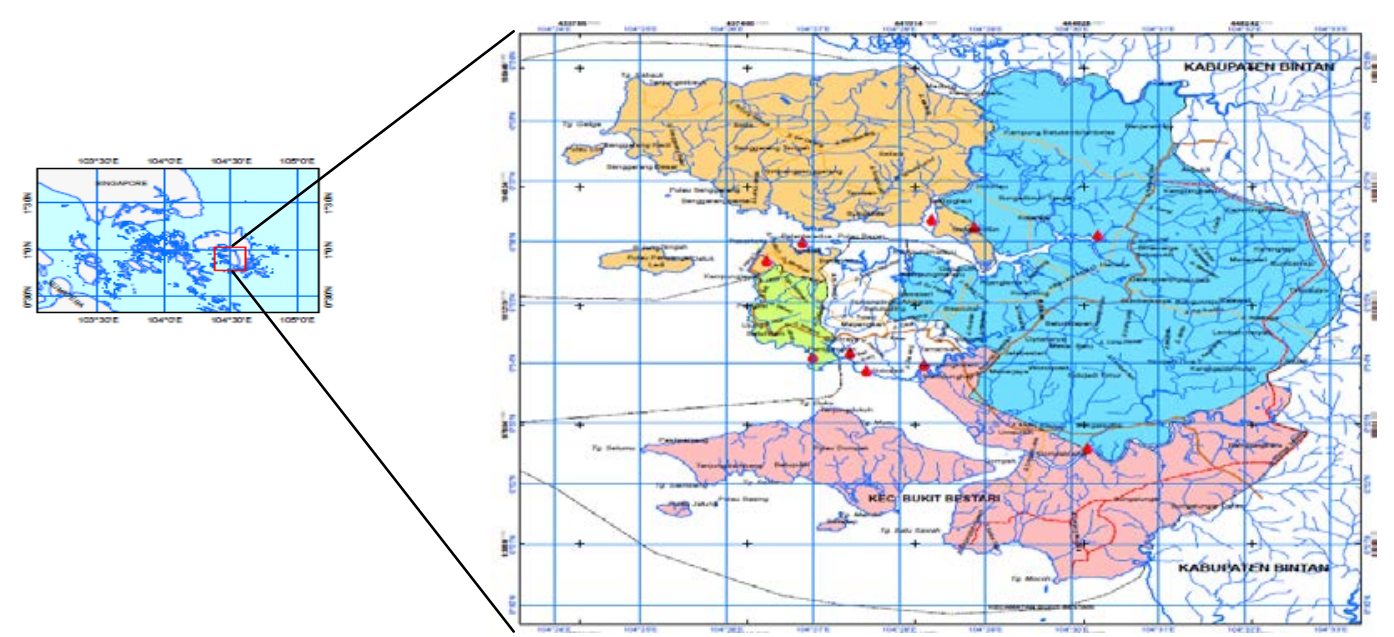

Gambar 1. Peta Lokasi pengambilan sampel di perairan kota Tanjungpinang

\section{HASIL DAN PEMBAHASAN}

\subsection{Beban Pencemar}

Mengingat Kota Tanjungpinang sebagai kota jasa, maka kegiatan industri kurang berkembang, sehingga yang berkembang adalah industri skala menengah dan kecil, dan didominasi oleh industri makanan dan minuman, diikuti oleh industri garmen (Tabel 2).

Dari jumlah industri diatas, industri yang menghasilkan limbah B3 yang ada di kota Tanjungpinang tidak banyak yaitu berjumlah 13 industri, dan industri yang berkembang adalah industri skala menangah dan kecil, sehingga limbah B3 yang dihasilkan berasal dari industri menengah dan kecil, rumah sakit, perbengkelan, pembangkit tenaga listrik. Limbah B3 yang dihasilkan berupa oli bekas, peralatan medis yang berupa limbah cair dan padat yang berupa infecqious.

Dari industri penghasil limbah B3 di kota Tanjungpinang dapat dikelompokkan menjadi 4 (empat) katagori yaitu: pertambangan, konstruksi, kesehatan dan energi. Untuk lebih jelasnya volume limbah B3 yang dihasilkan oleh industri di Kota Tanjungpinang disajikan dalam Gambar 2. 
Tabel 2. Profil Industri Kecil dan menengah Kota Tanjungpinang

\begin{tabular}{|l|c|c|}
\hline \multicolumn{1}{|c|}{ Kelompok Industri } & Jumlah P & \% \\
\hline industri makanan dan minuman & 164 & 84,54 \\
\hline industri perhiasan (barang logam) & 1 & 0,52 \\
\hline industri pakaian jadi & 12 & 6,19 \\
\hline industri barang dari plastik & 2 & 1,03 \\
\hline industri bahan galian & 3 & 1,55 \\
\hline industri alat transportasi lain & 6 & 3,09 \\
\hline industri mesin-mesin listrik & 1 & 0,52 \\
\hline industri kayu/furniture & 4 & 2,06 \\
\hline industri percetakan & 1 & 0,52 \\
\hline & $\mathbf{1 9 4}$ & $\mathbf{1 0 0}$ \\
\hline
\end{tabular}

Sumber: BLH Prov. Kepri, 2012

Secara umum menunjukkan bahwa kondisi perairan di kota Tanjungpinang telah tercemar logam berat, hal ini ditunjukkan oleh logam-logam terebut melebihi ambang batas yang telah ditentukan berdasarkan Kepmen-LH No. 51 Tahun 2004, yakni untuk logam-logam Arsen (As), Kadmium (Cd), Tembaga ( $\mathrm{Cu}$ ), Timbal (Pb), Seng (Zn), dan Nikel (Ni). Logam-logam yang terkait dengan aktivitas manusia di bidang industri perkapalan yakni $\mathrm{Pb}$ dan $\mathrm{Zn}$ yang merupakan komponen utama dalam cat. Sedangkan kompoisi logam berat seperti Arsen (As), Kadmium (Cd), Tembaga ( $\mathrm{Cu}$ ) diduga berasal dari aktivitas pertambangan bauxite di sekitar kota Tanjungpinang yang sudah berlangsung sejak zaman Belanda, sehingga kadar logam berat terakumulasi dalam perairan. Sementara itu, tingginya kadar nitrat dalam air merupakan penanda adanya aktivitas pertanian yang menggunakan pupuk dan sisanya terbuang ke perairan pantai di sekitar kota Tanjungpinang. Sedangkan pembuangan kotoran manusia memberikan dampak yang kurang baik terhadap lingkungan, yakni dengan adanya cemaran E. Coli di perairan Pelantar 1 dan Kampung Bugis yang merupakan permukiman padat. Beban pencemar kota Tanjungpinang disajikan dalam Tabel 3.

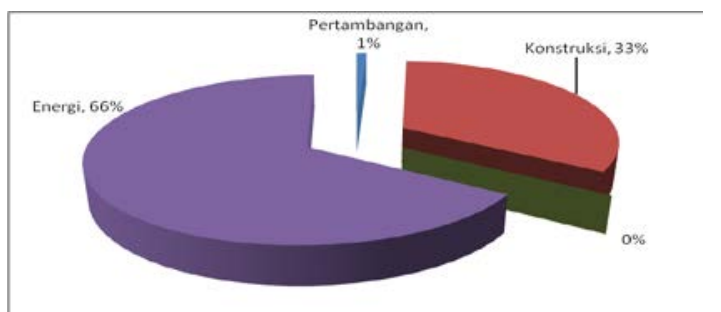

Sumber: BLH Prov. Kepri, 2012

Gambar 2 : Kelompok industri penghasil limbah B3 kota Tanjungpinang
Untuk menentukan apakah suatu daerah sudah tercemar atau belum, maka digunakan skala berdasarkan Kriteria Tingkat Pencemaran dan Kontaminasi (Pollution Load Index). Berdasarkan hasil perhitungan terlihat bahwa perairan di Lembah Purnama telah mengalami pencemaran dengan kriteria tercemar sedang (PLI skala 2-4) karena memiliki vegetasi bakau yang relatif baik sebagai remediasi pollutan, sedangkan perairan di Teluk Keriting telah mengalami pencemaran dengan kriteria tercemar parah (PLI skala 4-6), karena di perairan tersebut tidak memiliki vegetasi bakau yang dapat berfungsi sebagai remediasi pollutan, sehingga secara umum perairan kota Tanjungpinang sudah tercemar dengan kriteria sedang hingga parah seperti terlihat pada Tabel 4.

\subsection{Sedimen}

Sebagai pertimbangan dalam analisis kandungan unsur pencemar di perairan kota Tanjungpinang baik analisis kualitas air maupun sedimennya, maka dilakukan analisis kandungan logam-logam berat yang ada di dalam bauxite. Hasilnya adalah: baik dari endapan cucian bauksit maupun dari bauksit nya sendiri kandungan $\mathrm{Hg}$, As, $\mathrm{Cu}, \mathrm{Cr}, \mathrm{Pb}$, dan $\mathrm{Zn}$ sudah melebihi ambang batas yang telah ditentukan oleh Pemerintah. Unsur-unsur tersebut tercuci kemudian terbawa oleh air dan akhirnya masuk ke perairan kota Tanjungpinang dan diendapkan di sedimen, sehingga kandungan unsurunsur tersebut di badan air maupun di sedimen cukup tinggi (melebihi ambang batas) (BLHD Prov. Kepri, 2013).

\subsection{Pengaruh Kualitas Perairan Terhadap Biota}

Untuk mengetahui pengaruh pencemar diambil 15 (lima belas) biota dengan pertimbangan biota yang pergerakannya lambat (in situ) dan pergerakannya jauh yang meliputi: ikan dingkis (siganus canaliculatus), kerang kijing (Pilsbryoconcha exillis), ikan kerapu (Epinephelus tauvina), ikan timah-timah (Mystacoleucus lepturus), ketam atau kepiting bakau (Scylla sp.), ikan kakap putih (Lates calcarifer), ikan sembilang (Plotosus canius), ikan lebam (Siganus javus), siput gonggong (Strombus turturella), ikan ketang (Scatophagus argus), ikan usat (Plotopus spp.), ikan hibas (Siganus vermiculatus), ikan belanak (Mugil dossumien), Udang (Litopenaeus vannamei). dan ikan pasir (Hypostomus delimai). Hasil analisisnya disajikan dalam Gambar 3. 
Tabel 3. Beban pencemar perairan kotTanjungpinang

\begin{tabular}{|c|c|c|c|c|c|c|c|c|c|c|c|}
\hline & P1 & P2 & P3 & P4 & P5 & P6 & P7 & P8 & P9 & P10 & $\begin{array}{l}\text { BM utk } \\
\text { Biota laut }\end{array}$ \\
\hline$\left(\mathrm{NH}_{3}-\mathrm{N}\right)+$ & 0,102 & - & 0,09 & 0,093 & - & 0,180 & 0,091 & 0,109 & 0,094 & 0,105 & $0,3 \mathrm{mg} / \mathrm{L}$ \\
\hline$\left(\mathrm{PO}_{4}-\mathrm{P}\right)+$ & 0,010 & 0,005 & 0,006 & 0,006 & 0,006 & 0,011 & 0,021 & 0,019 & 0,012 & 0,032 & $\begin{array}{l}0,015 \\
\mathrm{mg} / \mathrm{L}\end{array}$ \\
\hline$(\mathrm{H} 2 \mathrm{~S})$ & $<0,001$ & $<0,001$ & $<0,001$ & $<0,001$ & $<0,001$ & $<0,001$ & $<0,001$ & $<0,001$ & $<0,001$ & $<0,001$ & $0,01 \mathrm{mg} / \mathrm{L}$ \\
\hline $\begin{array}{l}\text { Miny dan } \\
\text { Lemk }\end{array}$ & $<1$ & $<1$ & $<1$ & $<1$ & $<1$ & $<1$ & $<1$ & $<1$ & $<1$ & $<1$ & $1 \mathrm{mg} / \mathrm{L}$ \\
\hline $\mathrm{Cd}$ & 0,018 & 0,017 & 0,016 & 0,017 & 0,017 & 0,016 & 0,018 & 0,018 & 0,019 & 0,018 & $0,001 \mathrm{mg} / \mathrm{L}$ \\
\hline $\mathrm{Cu}$ & 0,015 & 0,013 & 0,0130 & 0,013 & 0,014 & 0,0140 & 0,014 & 0,014 & 0,012 & 0,015 & $0,008 \mathrm{mg} / \mathrm{L}$ \\
\hline $\mathrm{Pb}$ & 0,073 & 0,071 & 0,070 & 0,070 & 0,065 & 0,062 & 0,029 & 0,065 & 0,061 & 0,074 & $0,008 \mathrm{mg} / \mathrm{L}$ \\
\hline $\mathrm{Zn}$ & 0,068 & 0,065 & 0,065 & 0,063 & 0,064 & 0,070 & 0,072 & 0,078 & 0,073 & 0,094 & $0,05 \mathrm{mg} / \mathrm{L}$ \\
\hline $\mathrm{Ni}$ & 0,193 & 0,196 & 0,202 & 0,204 & 0,206 & 0,208 & 0,210 & 0,209 & 0,214 & 0,214 & $0,05 \mathrm{mg} / \mathrm{L}$ \\
\hline Ttl Colif. & 7 & - & - & - & 5 & - & - & - & - & - & $\begin{array}{l}1000 \\
\mathrm{MPN} / 100 \mathrm{~mL}\end{array}$ \\
\hline $\begin{array}{l}\text { Fecal } \\
\text { Coli }\end{array}$ & 4 & - & - & - & 2 & - & - & - & - & - & Nihil \\
\hline
\end{tabular}

Sumber: BLHD Provinsi Kepri, diolah, 2013.

Tabel 4. Perhitungan Tingkat Pencemaran dan Kontaminasi di perairan kota Tanjungpinang

\begin{tabular}{|c|c|c|c|c|c|c|c|}
\hline No. & Parameter & Satuan & $\begin{array}{c}\text { Cm } \\
\text { Lembah } \\
\text { Purnama }\end{array}$ & $\begin{array}{c}\mathrm{Cm} \\
\text { Teluk } \\
\text { Keriting }\end{array}$ & Baseline & $\begin{array}{c}\text { CF } \\
\text { (Lembah } \\
\text { purnama) }\end{array}$ & $\begin{array}{c}\text { CF } \\
\text { (Teluk } \\
\text { Keriting) }\end{array}$ \\
\hline 1 & $\begin{array}{l}\text { Raksa } \\
(\mathrm{Hg}) \\
\text { Arsen }\end{array}$ & $\mathrm{mg} / \mathrm{kg}$ & 110,96 & 396,24 & 0,05 & 2219,2 & 7924,8 \\
\hline 2 & $\begin{array}{l}\text { (As) } \\
\text { Tembaga }\end{array}$ & $\mathrm{mg} / \mathrm{kg}$ & 3,96 & 9,97 & 5 & 0,792 & 1,994 \\
\hline 3 & $\begin{array}{l}\text { (Cu) } \\
\text { Krom }\end{array}$ & $\mathrm{mg} / \mathrm{kg}$ & 9,47 & 19,15 & 5 & 1,894 & 3,83 \\
\hline 4 & $(\mathrm{Cr})$ & $\mathrm{mg} / \mathrm{kg}$ & 3,62 & 8,61 & 5 & 0,724 & 1,722 \\
\hline 6 & $\begin{array}{l}\text { Kadmium } \\
\text { (cd) }\end{array}$ & $\mathrm{mg} / \mathrm{kg}$ & 0,1 & 0,1 & 0,5 & 0,2 & 0,2 \\
\hline 7 & $\begin{array}{l}\text { Timbal } \\
\text { (Pb) }\end{array}$ & $\mathrm{mg} / \mathrm{kg}$ & 23,27 & 78,54 & 10 & 2,327 & 7,854 \\
\hline 8 & Zinc $(Z n)$ & $\mathrm{mg} / \mathrm{kg}$ & 60,11 & 124,71 & 20 & 3,0055 & 6,2355 \\
\hline & & & & & PLI & 2,913019 & 5,958069 \\
\hline
\end{tabular}

Sumber: BLHD Prov. Kepri, 2913 dan diolah

Biota dasar (demersal) yang pergerakannya lambat (terbatas) seperti kijing, ketam, gonggong, dan udang kandungan logam berat ( $\mathrm{Zn}, \mathrm{Cu}, \mathrm{Cr}, \mathrm{As}$ ) tinggi dan melebihi baku mutu, hal ini terkait dengan 
penambangan bauxite yang melepaskan unsur $\mathrm{Cu}$, As dan Zn. Untuk ikan-ikan palagis yang distribusinya luas seperti: timah-timah, kakap putih, lebam, ketang dan hibas kandungan $\mathrm{Zn}$ dan As cukup tinggi, hal ini terkait dengan industri perkapalan (shipyart) yaitu bahan cat. Untuk kandungan Zn kijing yang cukup tinggi disebabkan karena kijing mencari makan dengan cara menyaring makanan yang terlarut di dalam air (filter feeder), yang berupa detritus, alga bersel satu, dan bakteri (Word, 2012). Sedangkan untuk limbah domestik tidak berpengaruh secara signifikan terhadap biota perairan.

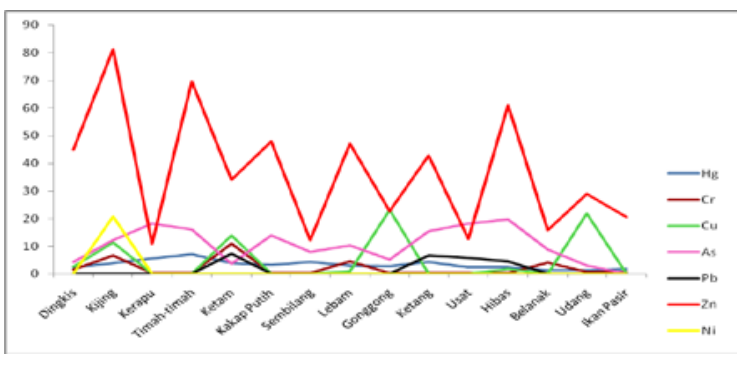

Gambar 3. Kandungan Logam terhadap tubuh biota perairan kota Tanjungpinang

\subsection{Pengaruh terhadap tubuh manusia}

Biota laut tersebut apabila dikonsumsi terus menerus oleh manusia, maka akan mengakibatkan gangguan terhadap kesehatan. Logam $\mathrm{Hg}$ yang berlebihan pada tubuh manusia akan berakibat: kerusakan berat dari jaringan paru. sedangkan keracunan makanan yang mengandung Mercury dapat menyebabkan kerusakan liver, $Z n$ yang berlebih akan mengakibatkan kerusakan berat hepar dan terjadi kegagalan ginjal akut. Beberapa efek yang ditimbulkan akibat pemajanan $\mathrm{Cd}$ adalah adanya kerusakan ginjal, liver, testes, sistem imunitas, sistem susunan saraf dan darah. Cu dalam jumlah kecil (1 $\mathrm{mg} / \mathrm{hr}$ ) penting dalam diet agar manusia tetap sehat, namun kadar $\mathrm{Cu}$ lebih tinggi dari normal akan mengakibatkan muntah, diare, kram perut dan mual, adan apabila kadarnya sangat tinggi dapat mengakibatkan kerusakan liver dan ginjal, bahkan sampai kematian. Tubuh menimbun timah selama seumur hidup dan secara normal mengeluarkan dengan cara yang lambat. Efek yang ditimbulkan adalah gangguan pada saraf perifer dan sentral, sel darah, gangguan metabolisme Vitamin D dan Kalsium sebagai unsur pembentuk tulang, gangguan ginjal secara kronis, dapat menembus placenta sehingga mempengaruhi pertumbuhan janin. Arsen (As) inorganik telah dikenal sebagai racun manusia sejak lama, yang dapat mengakibatkan kematian, dosis rendah akan mengakibatkan kerusakan jaringan. Efek yang timbul adalah iritasi saluran makanan, nyeri, mual, muntah dan diare, bahkan dapat mengakibatkan penurunan pembentukan sel darah merah dan putih, gangguan fungsi jantung, kerusakan pembuluh darah, luka di hati dan ginjal (Saeni, 1997).

Masukan untuk pemerintah kota Tanjungpinang dan Provinsi Kepulauan Riau adalah:

a. reforestasi yaitu melalui penanaman mangrove disepanjang pesisir dan muara sungai, dan moratorium penebangan mangrove, karena salah satu fungsi mangrove adalah penambat bahan-bahan pencemar yang berasal dari darat.

b. Penetapan kawasan konservasi laut daerah (KKLD) di Selat Dompak.

\section{KESIMPULAN DAN REKOMENDASI}

\subsection{Kesimpulan}

a. Perairan di sekitar Kota Tanjung Pinang Telah Tercemar logam berat dengan indeks pencemar sedang hingga parah yang meliputi: (a) pencemaran logam berat terutama berasal dari kegiatan penambangan bauksit yang sudah berlangsung lama $\mathrm{Hg}, \mathrm{Cd}, \mathrm{As}, \mathrm{Pb}, \mathrm{Cu},(\mathrm{b})$ pencemaran logam berat juga terkait dengan aktivitas transportasi yang melepaskan logam berat sebagai bahan tambahan bahan bakar $(\mathrm{Pb})$, (c) Pencemaran logam berat berupa $\mathrm{Pb}$ dan Zn terkait aktivitas industri di bidang perkapalan (shipyard) yang berasal dari bahan cat dan bahan tambahannya.

b. Kualitas Biota Perairan Kota Tanjungpinang telah tercemar logam berat yang telah mengalami bioakumulasi yakni $\mathrm{Hg}, \mathrm{Zn}$ dan $\mathrm{Ar}$ terkait aktivitas indusitri pengolahan bahan galian bauksit, dan biota terakumulasi paling tinggi pada Kijing ( $\mathrm{Hg}, \mathrm{Cr}, \mathrm{As}, \mathrm{Cu}, \mathrm{Zn}, \mathrm{NI})$, dan pada ikan-ikan dimersal lainnya yang distribusinya terbatas.

\subsection{Rekomendasi}

a. Moratorium penebangan mangrove dan mempertahankan yang ada disemua wilayah Kota Tanjungpinang

b. Penanaman mangrove di sepanjang muara sungai dan di pantai yang bersubstrat lumpur berpasir

c. Penetapan kawasan konservasi laut daerah (KKLD) di perairan selat Dompak.

\section{DAFTAR PUSTAKA}

1. Badan Lingkungan Hidup Daerah 2012, Studi Identifikasi Permasalahan dan Sistem Pengelolaan Limbah Industri di Provinsi 
Kepulauan Riau, Laporan Akhir, Badan Lingkungan Hidup Provinsi Kepulauan Riau.

2. Badan Lingkungan Hidup Daerah 2013, Studi Identifikasi Dampak Pencemaran Limbah B3 dan Domestik terhadap Biota Laut kota Tanjungpinang, Laporan Akhir, Badan Lingkungan Hidup Provinsi Kepulauan Riau.

3. Badan Pusat Statistik 2012, Kota Tanjungpinang dalam Angka 2011, Badan Pusat Satistik Provinsi Kepulauan Riau

4. Badan Pusat Statistik, 2014, Provinsi Riau Kepulauan dalam Angka 2013, BPS Provinsi Kepri

5. Bappeda 2012, Rencana Tata Ruang Wilayah Kota Tanjungpinang 2012 - 2022, Laporan Akhir, Badan Perencana Pembangunan Daerah Kota Tanjungpinang.

6. Maryuli Dyah Cahyani, Ria Azizah TN, Bambang Yulianto, 2012, Studi Kandungan Logam Berat Tembaga (Cu) pada Air, Sedimen, dan Kerang
Darah (Anadara granosa) di Perairan Sungai Sayung dan Sungai Gonjol, Kecamatan Sayung, Kabupaten Demak, Journal Of Marine Research. Volume 1, Nomor 2, Tahun 2012, Halaman 73-79 Online di: http://ejournals1.undip.ac.id/index.php/jmr

7. Saeni, M.S. 1997. Penentuan Tingkat Pencemaran Logam Berat dengan Analisis Rambut. Orasi IImiah, Guru Besar Tetap IImu Kimia Lingkungan, Fakultas Matematika dan IPA IPB. Bogor

8. Sembiring, Sastra, 2008, Sifat Kimia Dan Fisik Tanah Pada Areal Bekas Tambang Bauksit Di Pulau Bintan, Riau, Info Hutan Vol. V No. 2 : 123134, 2008.

9. Suwirma, S., Surtipanti, S., dan Thamsil, L. 1988. Distribusi Logam Berat $\mathrm{Hg}, \mathrm{Pb}, \mathrm{Cd}, \mathrm{Cr}, \mathrm{Cu}$, dan $\mathrm{Zn}$ dalam Tubuh Ikan. Majalah Batan. 9 (8) : 9-16 